\title{
Edukasi Dampak Covid-19 Melalui Komik serta Pembagian Masker dan Sembako bagi Masyarakat Terdampak Covid-19 di Kelurahan Panjehang Kota Palangka Raya
}

\section{Education on the Impact of Covid-19 through Comics and Distribution of Masks and Basic Food for Covid-19 Affected Communities in Panjehang Village, Palangka Raya City}

\author{
Srie Rosmilawati ${ }^{*}$ \\ Mita Sari ${ }^{2}$ \\ Sirojul Rahman ${ }^{1}$ \\ Yustin 1 \\ Isti Qomah ${ }^{1}$ \\ ${ }^{1}$ Department of Communication \\ Sciences, Universitas Muhammadiyah \\ Palangkaraya, Palangka Raya, Central \\ Kalimantan, Indonesia

$\begin{array}{lr}\text { 2Department of } & \begin{array}{r}\text { Public } \\ \text { Admininstration, }\end{array} \\ \text { Muhammadiyah } & \text { Palangkaraya, } \\ \text { Palangka Raya, Central Kalimantan, } \\ \text { Indonesia }\end{array}$ \\ email: milakpid@gmail.com

\section{COVID-19 \\ Komik \\ Masker \\ Sembako \\ Keywords: \\ COVID-19 \\ Comic \\ Face mask \\ Education \\ Groceries} \\ Kata Kunci \\ Pendidikan \\ Received: December 2020 \\ Accepted: February 2021 \\ Published: April 2021
}

\begin{abstract}
Abstrak
Negara-negara di dunia kini sedang dihadapkan pada tantangan besar penanganan wabah virus corona yang secara resmi diidentifikasi oleh WHO sebagai Corona Virus Disease-19 atau disingkat Covid-19. Pandemi yang bermula dari Kota Wuhan, Cina, ini telah menimbulkan global shock karena memang dalam beberapa dekade terakhir belum pernah kita mengalami serangan wabah virus dengan tingkat dan daya tular begitu cepat dan masif seperti virus corona ini, jauh di atas sepupunya virus SARS dan MERS, serta Ebola yang juga sempat mengacam beberapa tahun yang lalu, namun dengan cepat dapat teratasi. Aksi edukasi dampak Covid-19 sangat diperlukan untuk memberikan pemahaman kepada masyarakat Desa Panjehang dimana edukasi tersebut memuat tentang apa itu Covid-19, dampak dan bahayanya, serta cara mencegah penyebaran Covid-19 dan dilanjutkan pembagian paket sembako.
\end{abstract}

\begin{abstract}
Countries in the world face a big challenge in handling the coronavirus outbreak, which is officially identified by WHO as Corona Virus Disease19 or abbreviated as Covid-19. This pandemic, which started in the city of Wuhan, China, has caused a global shock because, in the last few decades, we have never experienced a viral outbreak with such a rapid and massive rate and transmission rate like this coronavirus, far above its cousins SARS and MERS viruses as well as Ebola, which had been tormented a few years ago, but was quickly resolved. Educational action on the impact of Covid19 is very much needed to provide understanding to the people of Panjehang Village where the education contains what Covid-19 is, its effects and dangers, and how to prevent the spread of Covid-19 and to continue the distribution of food packages.
\end{abstract}

(C) 2021 Srie Rosmilawati, Mita Sari, Sirojul Rahman, Yustin, Isti Qomah. Published by Institute for Research and Community Services Universitas Muhammadiyah Palangkaraya. This is Open Access article under the CC-BYSA License (http://creativecommons.org/licenses/by-sa/4.0/). https://doi.org/10.33084/pengabdianmu.v6i3.1878 


\section{PENDAHULUAN}

Pandemi korona virus di Indonesia diawali dengan temuan penderita penyakit korona virus 2019 (COVID19) pada 2 Maret 2020. Hingga 12 Mei, telah terkonfirmasi 14.749 kasus positif COVID-19 dengan 10.679 kasus aktif, 3.063 kasus sembuh, dan 1.007 kasus meninggal. Ada banyak spekulasi yang berkembang terkait asal muasal virus ini, dari yang menyebut berasal dari hewan, kelelawar, buatan manusia, hingga tak kurang yang mencurigai virus ini sebagai senjata biologis yang sengaja diciptakan untuk tujuan-tujuan tertentu (Nie, 2020). Tentu kita tak berkepentingan terlibat lebih jauh dalam polemik dan ragam praduga ini, karena memang tidak ada yang lebih menyita perhatian dan energi kita untuk saat ini dan ke depan, selain dampak besar yang ditimbulkan pandemi Covid-19 ini. Kita bisa melihat hanya dalam beberapa bulan saja sejak kemunculannya pada Januari lalu pandemi Covid-19 telah menimbulkan dampak yang sangat serius pada hampir seluruh aspek kehidupan manusia di muka bumi (Sari, 2020; Yamali \& Putri, 2020). Terutama di sektor ekonomi, meskipun jika kita mau objektif pandemi ini juga telah memberi dampak positif terhadap perbaikan kondisi ekologis bumi-dengan skala dan luasan yang tidak main-main: global, worldwide, seluruh negara di dunia merasakannya (Hadiwardoyo, 2020; Burhanuddin \& Abdi, 2020).

Dampak terbesarnya adalah mengganggu proses produksi, distribusi, dan konsumsi akibat tingkat dan skema penularan virus yang menyerang aspek paling fundamental dari seluruh akivitas kita, yaitu interaksi fisik antarmanusia hingga memaksa kita menerapkan kebijakan social/physical distancing. Sebagai instrumen utama penggerak aktivitas ekonomi, tentu ini akan sangat berdampak. Meskipun ekonomi kita sudah mulai bergerak ke arah digital, namun trend ini tidak cukup kuat untuk menjadi alternatif solusi atas dampak masif dan luar biasa pandemi Covid-19 ini (Newbold et al., 2020; Cheval et al., 2020).

Dunia/pelaku usaha baik skala besar maupun menengah kini sudah mulai kelimpungan. Proses input dan output ekonomi macet. Banyak perusahaan menutup usaha dan pabriknya akibat transaksi perdagangan mengalami penurunan akibat kurangnya pembeli serta terbatasnya ekspor sehingga mengalami penurunan omset (Aday \& Aday, 2020). Kemudian Pemberhentian Hak Kerja (PHK) terjadi dimana-mana, baik buruh pabrik, karyawan hotel, usaha angkutan, transportasi, tempat-tempat pariwisata, dan banyak sektor jasa lainnya. Masyarakat kecil pelaku usaha mikro, sektor riil, hingga petani, pedagang, nelayan, dan buruh yang mengandalkan pendapatan harian bahkan mengalami dampak yang lebih parah hingga kondisi rentan pangan dan ancaman kelaparan (Sugihamretha, 2020).

Sampai sejauh ini kita belum bisa memastikan kapan pandemi Covid-19 ini akan berakhir, yang jelas kondisi ini akan mengakibatkan aktivitas ekonomi perdagangan baik tingkat lokal, regional, dan internasional akan mengalami ketidakpastian, bahkan sampai pada ancaman berhenti total (Muhyiddin, 2020). Negeri kita meski kita memiliki sumber daya alam yang berlimpah, namun kekayaan alam tersebut belum bisa menciptakan kemandirian ekonomi sehingga masih ada ketergantungan pada negara lain. Diperparah oleh pandemi Covid-19, maka jelas target pertumbuhkan ekonomi kita tidak akan dapat tercapai.

\section{METODOLOGI}

Kegiatan "Edukasi Dampak Covid-19 melalui Komik dan Pembagian Masker serta Sembako bagi Masyarakat terdampak Covid-19 di Kelurahan Panjehang, Kecamatan Rakumpit Kota Palangka Raya" ini dilaksanakan oleh Universitas Muhammadiyah 
Palangkaraya melalui Fakultas Ilmu Sosial dan Ilmu Politik, Program studi ilmu administrasi negara danilmu komunikasi. Pelaksanaan kegiatan ini akan dilaksanakan secara berkala yang akan diadakan pada bulan Mei. hingga Juni selama beberapa hari di kelurahan yang ada di Kota Palangka Raya. Format Kegiatan yang dilakukan adalah Sosialisasi turun kelapangan membagi komik serta memberikan edukasi dan menjelaskan isi komik dan sosialisasi tentang protokol kesehatan kepada masyarakat tersebut, kemudian dilakukan juga Pembagian Masker dan sembako.

Narasumber dalam kegiatan ini disampaikan oleh Srie Rosmilawati, M.I.Kom., Mita Sari, S.Sos., M.A.P, dan Sirojul Rahman, S.Hut, M.I.Kom. Materi Kegiatan yang disampaikan adalah seputar covid-19, mengajarkan bagaimana protokol kesehatan untuk penanganan covid-19, membagikan Komik berkaitan dengan edukasi covid-19, membagikan masker dan sembako, kemudian memberikan pemahaman kepada masyarakat pentingnya kepedulian antar sesama di tengah covid-19.

\section{HASIL DAN PEMBAHASAN}

Beberapa kegiatan yang telah dilakukan dalam program PKM ini meliputi persiapan, koordinasi, pembukaan dan sosialisasi, pelaksanaan kegiatan (Edukasi Dampak Covid-19 melalui Komik dan Pembagian Masker serta Sembako bagi Masyarakat terdampak Covid-19 di Kelurahan Panjehang, Kecamatan Rakumpit Kota Palangka Raya).

\section{Persiapan}

Tahap ini dilakukan sebelum pelaksanaan PKM, yaitu Rapat Persiapan Perencanaan, melakukan koordinasi internal tim pelaksana, membuat rencana pelaksanaan berupa jadwal dan tempat pelaksanaan. Pembuatan Komik sebagai bahan Edukasi, dan persiapan bahan edukasi seperti membeli paket sembako, serta dokumentasi. Selanjutnya Koordinasi dengan Mitra yaitu Kelurahan Panjehang, Kecamatan Rakumpit Kota Palangka Raya, dan menemui langsung Lurah Panjehang Pak Dianto, SE dan memohon fasilitasi tempat kegiatan dan jumlah masyarakat untuk menjadi peserta kegiatan.

2. Pelaksanaan

Pelaksanaan kegiatan dimulai dengan pembukaan dan dilanjutkan dengan memberikan Edukasi Dampak Covid-19 melalui Komik dan Pembagian Masker serta Sembako dan pemberian cinderamata dan juga membagikan komik kepada masyarakat Desa Panjehang. Dokumentasi kegiatan yang dilaksanakan disajikan pada Gambar 1 sampai 6, sementara contoh desain komik layanan masyarakat yang dibagikan disajikan pada Gambar 7.

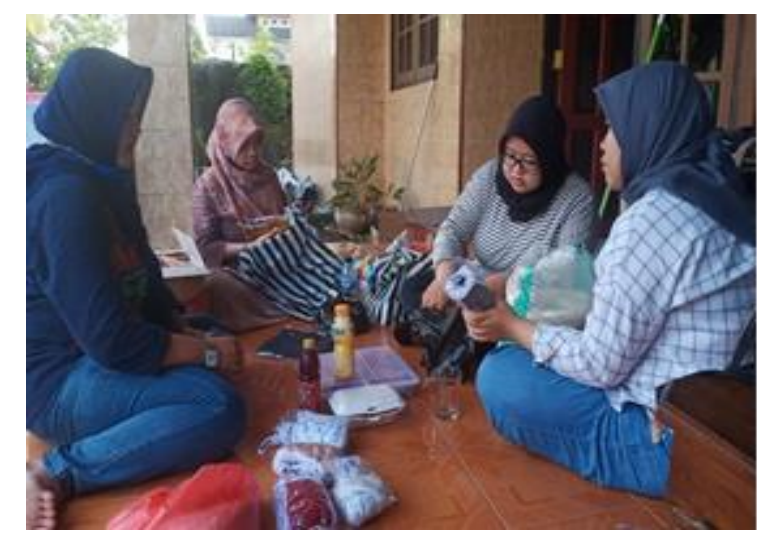

Gambar 1. Persiapan bingkisan masker, sembako, serta komik untuk dibagikan

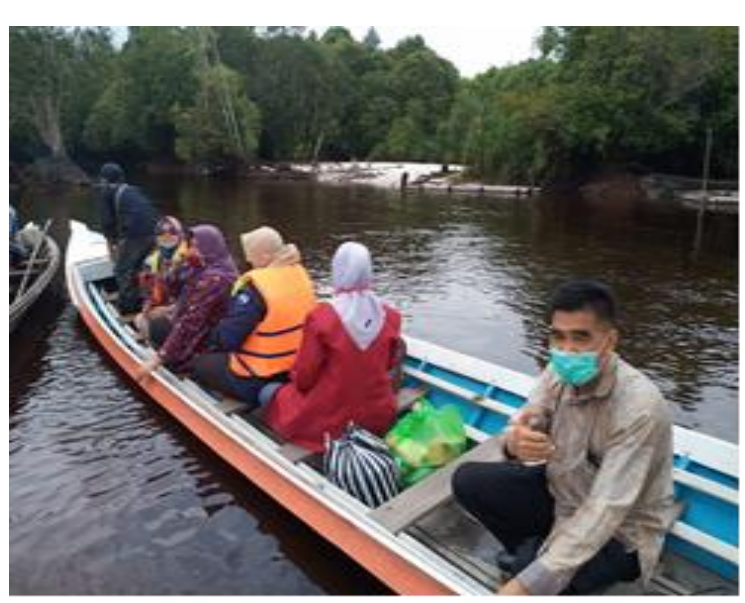

Gambar 2. Distribusi paket bantuan menggunakan transportasi air 


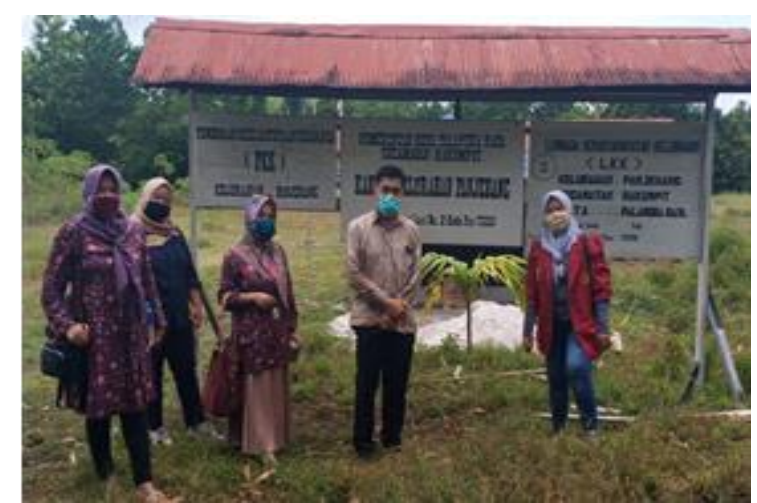

Gambar 3. Lokasi pembagian bantuan Kepada masyarakatdi Kelurahan Panjehang

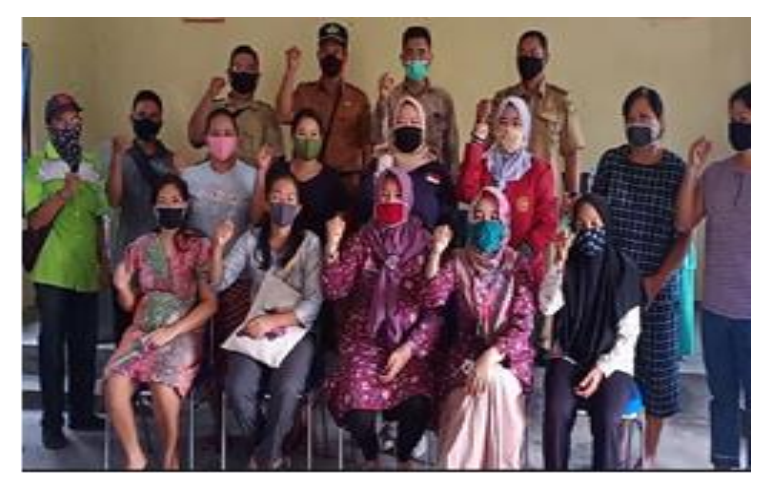

Gambar 4. Foto Bersama perwakilan tokoh masyarakat dan perangkat desa

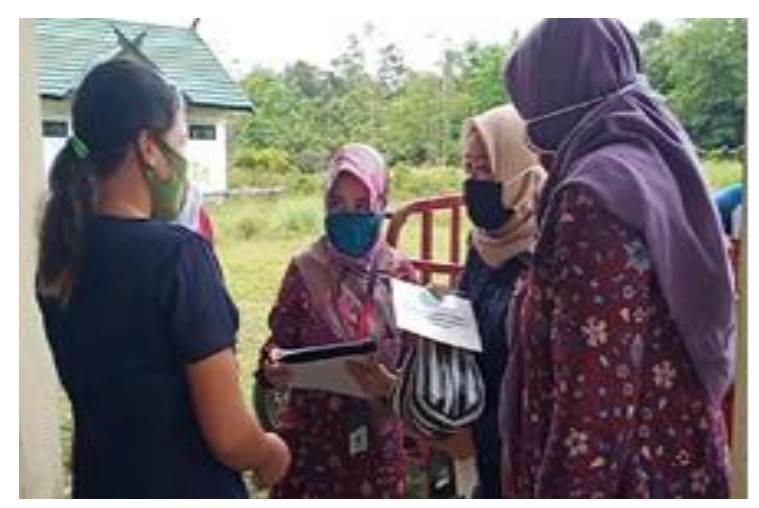

Gambar 5. Penyerahan paket bantuan Kepada masyarakat

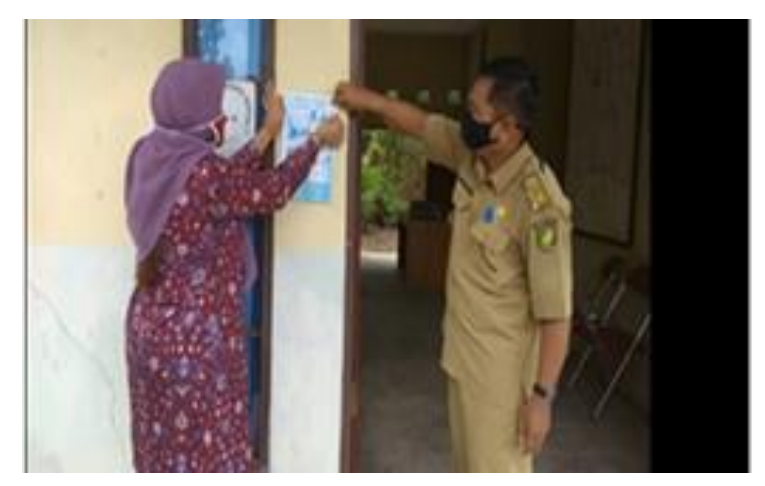

Gambar 6. Penempelan komik layanan masyarakat di fasilitas umum

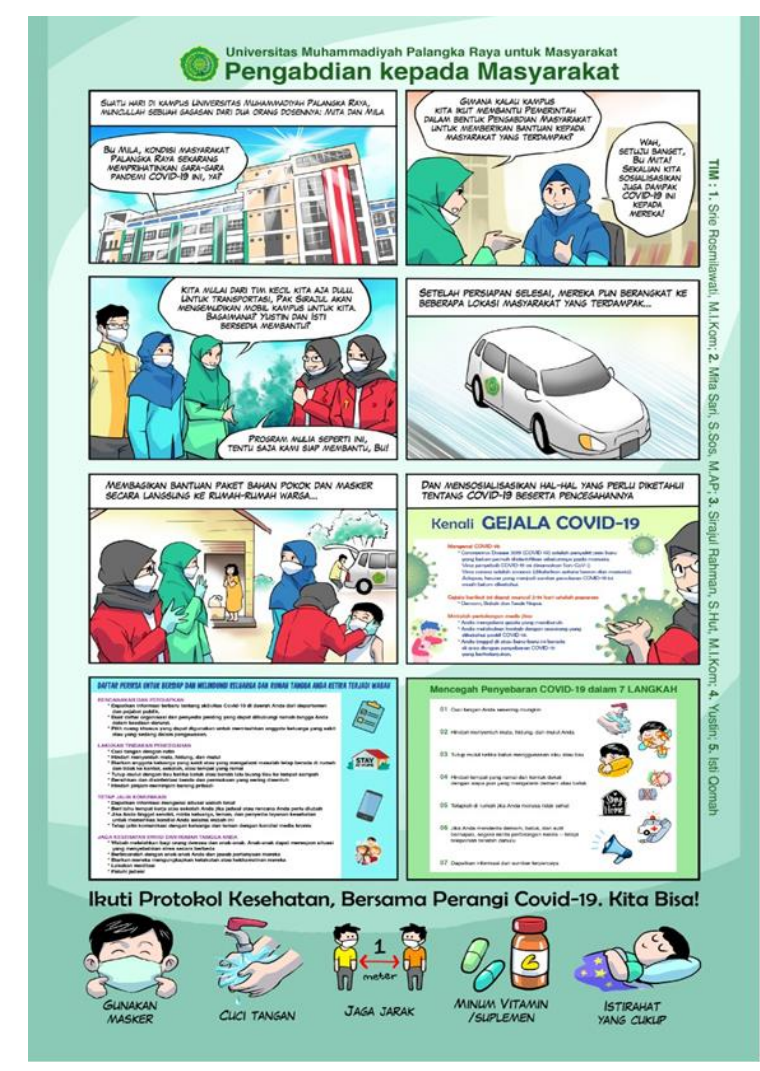

Gambar 7. Komik layanan masyarakat untuk masyarakat Desa Panjehang

3. Monitoring dan evaluasi

Setelah pelaksanaan edukasi, selanjutnya dilakukan monitoring dan evaluasi terdiri dari hasil kegiatan berupa tercapainya target jumlah peserta yang mengikuti Kegiatan Pengabdian Kepada Masyarakat Edukasi Dampak Covid-19 melalui Komik dan Pembagian Masker sebanyak 30 orang yang terdiri dari masyarakat Desa Panjehang. Selain itu, indikator lain berupa tersampaikannya materi-materi kegiatan kepada peserta diantaranya Materi Kegiatan yang disampaikan adalah seputar covid-19, mengajarkan bagaimana protokol kesehatan untuk penanganan covid-19, membagikan Komik berkaitan dengan edukasi covid 19, membagikan masker dan sembako, kemudian memberikan pemahaman kepada masyarakat pentingnya kepedulian antar sesama di tengah covid-19. Selain itu juga dilakukan Publikasi kegiatan melalui media sosial, Web Media Online dan Video Channel Youtube dengan tautan berikut: 
a. Betang TV: https://betang.tv/pkm-dipanjehang-dosen-dan-mahasiswi-fisip-umplakukan-ini/

b. YouTube: https://youtu.be/IY6Ui6eEVks

c. Instagram: https://www.instagram.com/tv/CEuOyDJJQ 9N/?igshid=1t7u96jqlu49z

d. Instagram: https://www.instagram.com/tv/CEuOyDJJQ 9N/?igshid=oxpt2jpvrcko

e. Metro Kalimantan: https://www.metrokalimantan.com/2020/09/ gelar-pengmas-di-panjehang-fisipump.html?m=1

Pandangan terhadap Pelaksanaan dan Materi, Secara umum peserta memberikan pandangan yang positif terhadap pelaksanaan kegiatan dan peserta berpendapat materi yang disampaikan narasumber sangat menarik dan bermanfaat, Hal ini terlihat dari antusias peserta yang banyak mengajukan pertanyaan serta ada beberapa peserta yang mengharapkan bahwa kegiatan ini dapat dilakukan secara terus menerus, berkelanjutan dan luas lagi keberbagai lapisan masyarakat. Peserta berpendapat bahwa kegiatan ini dapat:

1. Memberikan ilmu pengetahuan dan pengajaran kepada masyarakat Desa Panjehang mengenai covid-19, bagaimana protokol kesehatan untuk penanganan covid-19

2. Dengan adanya pembagian paket sembako sangat Membantu masyarakat Desa Panjehang yang terdampak covid-19

3. Membagikan Komik berkaitan dengan edukasi covid-19, membagikan masker dan sembako, kemudian memberikan pemahaman kepada masyarakat pentingnya kepedulian antar sesama di tengah covid-19.

\section{KESIMPULAN}

Berdasarkan hasil dan serangkaian kegiatan yang sudah dilakukan seperti tersebut di atas maka dapat diambil kesimpulan bahwa semua tahapan kegiatan edukasi dampak covid-19 mulai dari penjelasan materi dapat dipahami dengan baik. Hal ini bisa dibuktikan ketika pelaksanaannya materi dapat diterima dengan mudah. Seluruh peserta menyatakan diri bahwa mereka sangat antusias dalam mengikuti kegiatan edukasi dampak covid-19 tersebut dan merasa materi sangat bermanfaat menambah pengetahuan mereka tentang seputar covid19, dan mengajarkan bagaimana protokol kesehatan untuk penanganan covid-19. Diperlukan dukungan dari semua pihak terkait untuk keberlanjutan kegiatan ini, sehingga bisa menjadikan masyarakat lebih paham, waspada dan menyadari dampak covid-19.

\section{UCAPAN TERIMA KASIH}

Ucapan terima kasih kami sampaikan kepada LP2M Universitas Muhammadiyah Palangkaraya yang telah mendanai kegiatan pengabdian tahun ini.

\section{REFERENSI}

Aday, S., Aday, M.S. 2020. Impact of COVID-19 on the food supply chain. Food Quality and Safety. 4(4):167-180. https://doi.org/10.1093/fqsafe/fyaa024

Burhanuddin, C.I., Abdi, M.N. 2020. Krisis Ekonomi Global Dari Dampak Penyebaran Virus Corona (COVID-19). AkMen Jurnal Ilmiah. 17(1):90-98. https://doi.org/10.37476/akmen.v17i1.866

Cheval, S., Adamescu, C.M., Georgiadis, T., Herrnegger, M., Piticar, A., Legates, D.R. 2020. Observed and Potential Impacts of the COVID-19 Pandemic on the Environment. International Journal of Environmental Research and Public Health. 17(11):4140. https://dx.doi.org/10.3390/ijerph17114140 
Hadiwardoyo, W. 2020. Kerugian Ekonomi Nasional Akibat Pandemi COVID-19. Baskara: Journal of Business and Entrepreneurship. 2(2):83-92. https://doi.org/10.24853/baskara.2.2.83-92

Muhyiddin, M. 2020. Covid-19, New Normal, dan Perencanaan Pembangunan di Indonesia. Jurnal Perencanaan Pembangunan: The Indonesian Journal of Development Planning. 4(2):240-252.

https://doi.org/10.36574/jpp.v4i2.118

Newbold, S.C., Finnoff, D., Thunström, T., Ashworth, M., Shogren, J.F. 2020. Effects of Physical Distancing to Control COVID-19 on Public Health, the Economy, and the Environment. Environmental and Resource Economics. 76:705729. https://dx.doi.org/10.1007/s10640-02000440-1

Nie, J.B. 2020. In the Shadow of Biological Warfare: Conspiracy Theories on the Origins of COVID19 and Enhancing Global Governance of Biosafety as a Matter of Urgency. Journal of Bioethical Inquiry. 17:567-574. https://dx.doi.org/10.1007/s11673-02010025-8

Sari, V.Y. 2020. Analisis Respons Pemerintah Tiongkok dalam Upaya Penanganan Covid-19. Sentris. 1(2):173-186.

https://doi.org/10.26593/sentris.v1i2.4284.17 3-186

Sugihamretha, I.D.G. 2020. Respon Kebijakan: Mitigasi Dampak Wabah Covid-19 Pada Sektor Pariwisata. Jurnal Perencanaan Pembangunan: The Indonesian Journal of Development Planning. 4(2):191-206.

https://doi.org/10.36574/jpp.v4i2.113

Yamali, F.R., Putri R.N. 2020. Dampak Covid-19 Terhadap Ekonomi Indonesia. Ekonomis: Journal of Economics and Business. 4(2):384-388. http://dx.doi.org/10.33087/ekonomis.v4i2.1 79 